\title{
The rise and flaws of green growth
}

Manu V. Mathai ${ }^{\mathrm{a}}{ }^{*}$, Jose A. Puppim de Oliveira ${ }^{\mathrm{b}}$, and Gareth Dale ${ }^{\mathrm{c}}$

a Azim Premji University, India

b Fundação Getulio Vargas (FGV/EAESP and FGV/EBAPE), Brazil

c Brunel University, U.K.

*Corresponding author.Email:manu.mathai@apu.edu.in

\section{ABSTRACT}

Green growth has gained ground in environmental governance deliberations and policy proposals in the last decades. It was initially presented as a fresh and innovative agenda centred on the deployment of engineering sophistication, managerial acumen, and market mechanisms to redress the environmental and social derelictions of the existing development model. But can the green growth project deliver environmental sustainability, social justice and the achievement of economic life upon a materially finite planet? The article argues that green growth has several theoretical flaws and empirical limitations. Even though economic growth has brought tremendous benefits to society, continued economic growth in rich countries faces difficulties, and growth per se is not delivering the benefits for the wider society in terms of quality of life, happiness and health, and environmental sustainability. Unlimited growth poses tremendous challenges to the planetary health, with implications in the long term. Within this context, the article ends with a discussion about the merits and demerits of alternative strategies and policies, asking the vital question: If not green growth, then what?

\section{INTRODUCTION}

"Green growth", together with the related 'green economy,' represents the latest phase in the reconstruction of political discourse in face of ecological challenges and environmental movements. It encompasses approaches ranging from geo-engineering mega-projects to routine "efficiency strategies". By such means, green growth promises to stem the environmental crisis and mitigate its consequences whilst simultaneously addressing social challenges of destitution and disempowerment by accelerating economic growth. Green growth is a project with a utopian charge, depicting a path to the future that, thanks to scientific insight, engineering sophistication and managerial smartness, claims to be capable of redressing the accumulated harms of the "old" industrial paradigm. At the same iants, it claims to embody a sober realism: the route towards a sustainable future maintains, and even reinforces, the institutional and normative territory of the current political economic prevalent ideas.

Taken at face value, green growth appears impervious to critique. Economic growth is taken as good, imperative, essentially limitless, and a matter of pressing concern for society as a whole. And time, at least in its mainstream var-

\section{KEYWORDS}

Capitalism, Ecological modernization, Environmental Kuznets Curve, Green growth, Neoclassical economics

DOI

https://doi.org/10.30852/sb.2018.359

\section{DATES}

Received: 21 December 2016

Published (online): 11 May 2018

Published (PDF): 26 December 2018

\section{HIGHLIGHTS}

» There are many theoretical and empirical shortcomings in the ideas behind green growth

» The experiences of green growth in practice have not presented the promised results

»Ecological modernization has several limitations to keep the planetary boundaries

» Several alternatives to the green growth discourse exist

» The core of the alternatives is re-establishing social control over the economy 
green growth owes much of its influence given that it charts a pathway for continued economic growth even in the face of the environmental crisis and criticisms thereof. Further, the project of economic growth is not easily dislodged. It flows from fundamental societal transformations associated with the advent of modernity (the linearization of time, the notion of progress, the dissolution of just wage norms, and the quantification of processes of wealth, production and distribution). Institutionally, the growth imperative is an inherent attribute of the capitalist mode of production exacerbated under the neoclassical economics paradigm. This capitalism "distinguishes itself from all other socio-economic systems in human history by the movement towards the infinite"; its totalising logic penetrates society in all its facets and converts "almost the entire world into a field of valorisation" (Mahnkopf, 2016) through "the process of competitive, blind accumulation that grants to capitalism its distinctive requirement for relentless growth" (Meadway, 2016).

In an early effort to characterize and justify the economic growth paradigm, Adam Smith speculated that it is "in the progressive state," when society "is advancing to the further acquisition, rather than when it has acquired its full complement of riches that the condition of the labouring poor, of the great body of the people, seems to be the happiest" (Smith, 1776, p. 81). It is in a state of continual economic growth that emancipatory potential is achieved, and not just wealth. And, indeed, the subsequent two centuries of industrial capitalism did significantly advance the "acquisition of riches," as well as raise life expectancy, erode feudal and patrimonial forms of personal economic dependence, and catalyse advances in individual liberty and democracy that, although geographically very uneven in quality and application, were global in scale and momentous in scope.

This narrative of the "progressive state" of capitalist modernity is now struggling to retain its coherence in three respects. One is internal to the growth paradigm itself. The system's own yardstick of success, GDP per capita growth (annual \%), has for several decades followed a flat and even downward trajectory in many countries (World Bank, 2017). Although global capitalism is systemically "compelled towards growth," it appears to be "decreasingly able to deliver it" (Meadway, 2016). The second is a scepticism vis-à-vis the "Smithian promise" that growth will emancipate the poor. Against a backdrop of vulgar levels of income inequality, the supposed connection between economic growth and social wellbeing has been increasingly called into question by prominent studies (Stiglitz, Sen \& Fitoussi, 2009). Some critics argue that "just when the human species discovers that the environment cannot absorb further increases in emissions, we also learn that further economic growth in the developed world no longer improves health, happiness or wellbeing" (Pickett \& Wilkinson, 2009; p.215).

The third is a growth scepticism fuelled by concerns over the diminishing ecological space available to supply non-renewable resources and to absorb the effluents of ongoing growth. Ecological thresholds are being breached, and "tipping points" appear to be upon us (Rockstrom et al., 2009). To this, the dominant response has long been one or another variant of "green growth": the idea that investment in the production of knowledge and science, the resulting innovations in technique, environmental awareness that purportedly comes with rising incomes, and a structural shift toward less resource- and energy-intensive service sector industries will "save the planet" (Tierney, 2009). In its formalized version, this idea came to be known as the Environmental Kuznets Curve (EKC). The EKC holds that, after a certain point, economic growth correlates strongly with greater efficiency in resource use. However, the idea that a simple, inverse relationship exists between per capita income and environmental stress has been challenged on a number of counts. For example, the idea that caring about the environment is a privilege of rich people is baseless; it ignores the "environmentalism of the poor" (Down to Earth, 1993, Martinez-Alier et al., 2016 and Kothari, 2016). Moreover, the EKC hypothesis has held in particular conditions, with respect for example to pollutants that have short-term costs, such as particulates, and not with respect to accumulating wastes or to pollutants involving long-term costs, such as greenhouse gas emissions (GHGs). The EKC hypothesis ignores the fact that reduced pollution in developed countries is often part of the same processes-above all, the outsourcing of manufacturing, and consequently pollution, to developing countries - that determine the expansion of resource-intensive production elsewhere (Sunderlin, 2003, p. 161).

A major hope of green growth advocates, on which much of their case rests, is that efficiency gains will negate overall increments in attendant energy and material throughput, including a dramatic reduction of GHG emissions. But this is much too sanguine, not least because it neglects to consider the "Jevons Paradox", which postulates that the improved technological efficiency in the utilization of a natural resource, within a capitalist framework, tends not to decrease but to increase its overall rate of consumption, because its relative cost is lessened and thereby increasing demand and freeing up capital for alternative uses (Jeavons, 1865). This is a key reason why the ability of efficiency strategies to successfully address the crisis in society-nature relations is likely to remain limited. 


\section{GREEN GROWTH IN PRACTICE}

On the one hand, energy efficiency measures have been adopted in different sectors by a large number of countries.Mandatoryefficiency regulation on finalenergy consumption has reached almost 25\% in 2014 (IEA, 2015). Indeed, primary energy intensity has declined in $80 \%$ of surveyed countries since 2014 through different measures such as energy efficiency programs and regulations, GHG regulations and transformation of economic activities (WEC, 2016). Primary energy intensity has improved in all regions of the world in the last two decades (ESCAP, UNEP, UNU \& IGES, 2016; see Figure 1). However, even though energy efficiency and clean energy have led to significant improvements in carbon intensity, there has been a sharp increase in global emissions, particularly in rapidly developing countries. This is because improvements in energy efficiency have not been sufficient to offset the rapid economic growth in emerging economies. For example, even though China reduced carbon emissions from fuel combustion per unit of GDP by $55 \%$ between 1990 and 2011, its emissions per capita tripled in the same period, and are now larger than the EU27 average, even though China is still much poorer (Hoffmann, 2016). The Republic of Korea, the main proponent of green growth, has also more than doubled its emissions per capita in the same period, though efficiency of carbon emissions from fuel combustion per unit of GDP increased by more than $8 \%$ in the same period. Indeed, South Korea's National Strategy for Green Growth and Five-Year Plan for Green Growth revealed by former president Lee was criticized for being based on nuclear energy expansion, land reclamation, canal cutting and dredging, and the construction of a multitude of dams and weirs - all of which would place further strain upon the country's beleaguered natural environment. It was little surprise when Lee's initiatives faced a barrage of criticism, and that the subsequent governments, under President Geun-hye Park, considered "ditching" green growth altogether (Shin, 2013).

Green growth is not expected to change the high growth in energy demand in emerging economies expected until 2040 (IEA, 2015). In order to offset emissions to reach the goals of the Paris Agreement (less than $2{ }^{\circ} \mathrm{C}$ increase in average temperature), the rate of decarbonisation needs to reach $6.3 \%$ per annum until 2100 ; in contrast the achieved rate in 2016, despite a marked improvement over historical rates (0.8\% between 2000 and 2011) was 2.6\% (PricewaterhouseCoopers LLP, 2017). The future of this trend is unclear, at best. For instance, improvement in energy efficiency seems to have weakened recently: its annual rate declined from $1.6 \%$ between 2000 and 2008 to $1.3 \%$ since then (WEC, 2016).

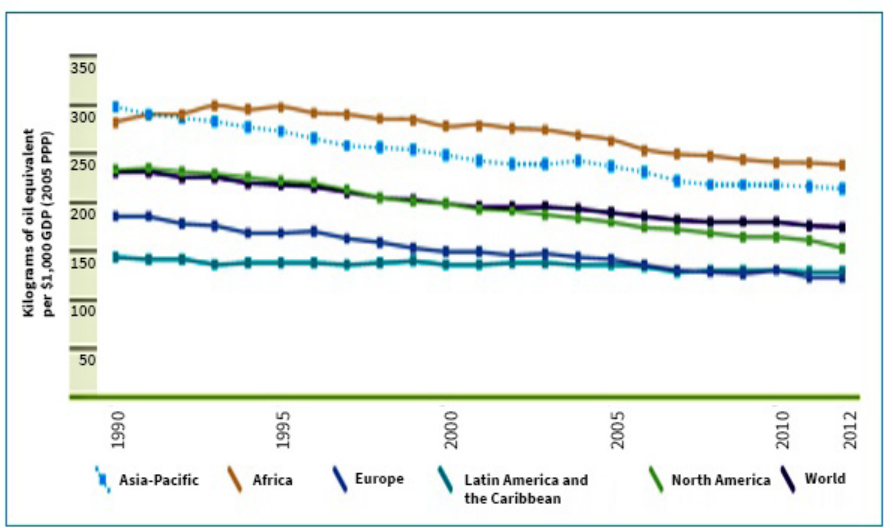

FIGURE 1. Primary energy intensity by region (1990-2012). Sources: ESCAP, UNEP, UNU and IGES, 2016 from ESCAP Asia Pacific Energy Portal, based on data from the International Energy Agency, World Energy Statistics and Balances and the United Nations Statistics Division National Accounts Main Aggregates Database.

\section{ALTERNATIVES}

Thus, greater efficiency (technical and economic) in the throughput of matter and energy is a necessary but insufficient condition for guiding energy and resource use policies in the present context. Sufficiency, along with efficiency, is an urgent necessity. Alternatives challenge the ideological commitments, policy choices and the resulting political economy that have shaped the contemporary world.

Green growth advocacy is not the last word in environmentalism, even if it is one of the loudest voices. Other voices point to different types of non-growth oriented forms of social organization. The question of alternatives may be unfolded from an analysis of the prevailing socio-economic system.

"Unbounded accumulation, the continuous extraction of surplus labour, is not simply a process of exploitation but undergirds a nexus of processes of alienation: of workers from the labour process, their products, their fellows, and their selves; and of labour itself-and human society in general-from nature. The system as a whole is administered by political institutions that service the requirements of capital and oversee the management and policing of population. Viewed in this way, a sustainable society will, ultimately, require the transcendence of, or breaking away from, the systemic, objective logic that dictates capital's ceaseless motions to produce and reproduce itself in ever widening spaces of commodified nature and society." Connected through these shared experiences of alienation and exploitation "labour struggles are environmental struggles, and vice versa" (Lohmann, 2016).

However, the convergence of different movements around transformative goals is never automatic. All social movements are criss-crossed with contestation and dialogical relations, internal debates and tensions. 
They find themselves pulled between imperatives to resist structures of capitalist power and to accommodate to it. The dilemmas faced by movements seeking sustainable alternatives to technocracy and to the capitalist growth model, and theoretical questions associated with them, are at the heart of the alternatives.

Progressive social movements recount numerous examples of resistance and creativity that demonstrate a radically different logic to that of industrial capitalism and state-led economic development. Among many cases in India, the "Dongria Kondh" adivasis, an indigenous group in the state of Odisha who decided not to allow a multinational mining company to take over their lands," justified their actions in terms of a logic radically different from the externalization and commodification of nature, namely the "sacredness of the land and forest, and their own notions of well-being" (Kothari, 2016).

In an effort to distil the principles that inform these efforts, labelled Radical Ecological Democracy (RED) (Kothari, 2016) distinguishes attributes that intuitively, if not explicitly, counter the totalizing logic of industrial capitalism. These include, but are not limited to, decentralized embedded political governance adhering to the principle of subsidiarity, the decentralization of economic life and economic localization, the recognition of equity and protection of diversity and breaking artificial boundaries and hierarchies of knowledge systems. Illustrations such as these point to a lived reality of alternative logics that fundamentally differ from the externalizing, commodifying, accumulation logic of state-led economic development. However, "peoples' movements will also have to recognize the fine line between policy-based expansion of democratic spaces that aid fundamental transformation, and those that the state uses to soften or even co-opt peoples' movements" (Kothari, 2016).

In another example of alternative, the community-based energy utility pioneered in the state of Delaware, USA, represents an effort to move the energy sector away from the conventional approach of atomized households served by a distant centralized utility with energy mined from an externalized, commodified nature (Taminiau \& Byrne, 2016). Teasing out the operative mechanism that grants the conventional energy-society relationship its daunting momentum, civil society has become reduced to a "consumer democracy" in which the ability of end-users of energy "to influence entrepreneurial and capitalistic activity is limited to their daily vote on the means of production through the global marketplace." As a Sustainable Energy Utility (SEU), the Delaware initiative envisions steering the energy sector away from "consumer democracy" to a role where consumers are also producers and, further, are envisioned as "sustainable citizens" engaged in energy conservation, energy efficiency and renewable energy commons. The SEU seeks to integrate energy (nature) and society in a democratically organized, decentralized and mutually co-producing relationship, representing a marked contrast to the centralized, and undemocratic nature-society model of the standard energy utility and its atomized customers. The SEU is an effort to reinterpret and reintegrate ideas of "commonwealth" and "community trust" into the energy discourse long severed from shared, commons-based practice and sensitivities.

Individuals and movements today stand upon terrain that is shaped by neoclassical economics. One of the more illuminating discussions of the possibilities and constraints in this regard is Heather Rogers' Green Gone Wrong. It explores, inter alia, experiments in agroecological farming, in which contingent successes could be achieved, with the deployment of efficient ecologically sustainable agricultural techniques, and the successful infusion of community engagement. Nonetheless, all enterprises, however mutual, social and ecological, face pressures to cut costs or risk losing customers to rivals: "The rules of the marketplace support the big guys"; "Small farmers typically can't make a larger environmental impact because our political and economic system won't let them" (Rogers, 2010). On one hand, many social movements for alternative political economies, such as workers' cooperatives, alternative currencies, and community-based agroecological farming, were driven by the application of creativity, innovation and idealism, combined with principles of mutuality and self-management, to serve goals of community, equality and ecology (Böhm, Misoczky, Watson, \& Lanka 2016). On the other hand, in each case compromises were made with major business concerns and with state power: the Small and Marginal Tribal Farmers Mutually Aided Cooperative Society (SAMTFMACS) in India and the Landless Workers' Movement (MST) in Brazil, the world's most powerful land reform movement, has in its capacity as economic agent entered into agreements with a transnational corporation, in a process that led the MST farmers involved to see themselves as "service providers" responding to market demands more than as the collective producers of "new socio-economic subjectivities" (Böhm et al., 2016).

In sum, alternatives may not happen without larger societal transformations through different governance structures to scale up the existing viable opportunities or local niches, as some discussed above, to the national and regional level. At the international level, both a sense of urgency and political change are needed to build up the political and economic interests required to reach a broad consensus over an effective governance structure that 
includes planetary limits in economic decisions and not only provide market-based solutions to environmental problems, which can exacerbate the problems. Indeed, the emphasis on growth and use of market mechanisms to promote sustainable development is already facing criticism in the international arena.

The underlying logic for finding alternatives to green growth is to move beyond the technocratic realm and the mainstream discourse propagating market capitalism as the only solution to the ecological and social crises of the 21st Century. Alternatives have to challenge the simple argument of mainstream "green economics" that the environmental crises can be solved by "internalizing" externalities through price mechanisms and changing the mix of inputs ("factors of production") in economic processes. Radical societal transformations ask for an overall change in the economic system and have many components, as pointed out by Ulrich Hoffmann (2016): we "...need to realize that the required transformation goes far beyond innovation and structural changes to include democratization of the economy, better distribution of income and wealth, power over markets, and a culture of sufficiency."

\section{CONCLUSION}

The language of green growth is alluring for a political economy mired in lingering economic lethargy, persistent poverty, rising inequality and stubborn environmental crises that persist and expand despite four decades of modern environmentalism. Collectively, these crises have undermined confidence in economic orthodoxy's assertion that growth is good, even necessary. Greening growth, thus, is a promise to heal that distrust - growth is good because it can be "green." In practice, however, this proposal has not withstood scrutiny. It holds an excessively narrow, even contrived, notion that technological efficiency (enabled through surplus from economic growth) amounts to ameliorating the cumulative and continuing social and ecological impacts of economic growth orthodoxy. Green growth projects have turned to authoritarian politics in pursuit of investments in heavy infrastructure projects and thereby undermining the very institutional foundations of democratic decision-making long recognized in the sustainable development literature. What is apparent to dispassionate inquiry is the limited nature of ecological modernization strategies, be they authoritarian or democratic.

The democratic version is necessary, but insufficient to redress our present crises. Acknowledging this evidence, many civil society actors across the world are instead in pursuit of alternatives to economic orthodoxy.
They have advanced alternatives that organize labour and control over consumption and production in ways that attempt re-embedding the economic system within society. These movements to counter the orthodoxy's arrangement of situating the economy in an autonomous and controlling position over society are foundational. They appear to proceed through resistance, innovation but also through accommodation. The path ahead is yet unclear but the goal is less so. Despite current ambiguity they are fertile and urgent grounds for innovation, experimentation and social change.

\section{REFERENCES}

Bluemling, B., \& Yun S-J. (2016). Giving green teeth to the Tiger? A critique of green growth in South Korea. In Dale, G., Mathai, M. V. and Puppim de Oliveira, J. A. (Eds.), Green Growth: Ideology, Political Economy and the Alternatives (pp. 114-130). London: Zed Books.

Böhm, S., Misoczky, M.C.A., Watson, D. \& Lanka, S. (2016). Alternatives to green growth? Possibilities and contradictions of self-managed food production. In Dale, G.; Mathai, M. V. and Puppim de Oliveira, J. A. (Eds.), Green Growth: Ideology, Political Economy and the Alternatives (pp. 253-269). London: Zed Books.

Dale, G., Mathai, M. V. and Puppim de Oliveira, J. A. (Eds.) (2016). Green Growth: Ideology, Political Economy and the Alternatives (pp. 90-111). London: Zed Books.

Down to Earth (1993). Chipko: Environmentalism of the Poor. Retrieved 11 August 2017, from: http://www. downtoearth.org.in/news/chipko-environmentalism-of-the-poor-30899

ESCAP, UNEP, UNU and IGES (2016). Transformations for Sustainable Development: Promoting Environmental Sustainability in Asia and the Pacific. Report edited by ESCAP, UNEP, UNU and IGES. Retrieved 16 November 2016, from http://www.unescap.org/publications/transformation-for-sdg

Hoffmann, U. (2016). Can green growth really work? A reality check that elaborates on the true (socio-) economics of climate change. In Dale, G., Mathai, M. V. and Puppim de Oliveira, J. A. (Eds.), Green Growth: Ideology, Political Economy and the Alternatives (pp. 22-41). London: Zed Books.

IEA - International Energy Agency (2015). World Energy Outlook (WEO 2015). IEA: Paris.

Jeavons, W. S. (1865). The Coal Question: An Inquiry Concerning the Progress of the Nation and the Probable Exhaustion of Our Coal-Mines. London and Cambridge: McMillan and Co.

Kothari, A. (2016). Beyond 'development' and 'growth': 
The search for alternatives in India towards a sustainable and equitable world. In Dale, G., Mathai, M. V. and Puppim de Oliveira, J. A. (Eds.), Green Growth: Ideology, Political Economy and the Alternatives (pp. 212-232). London: Zed Books.

Lohmann, L. (2016). What is the 'green' in 'green growth'? In Dale, G., Mathai, M. V. and Puppim de Oliveira, J. A. (Eds.), Green Growth: Ideology, Political Economy and the Alternatives (pp. 42-71). London: Zed Books.

Mahnkopf, B. (2016). Lessons from the EU: Why capitalism cannot be rescued from its own contradictions. In Dale, G., Mathai, M. V. and Puppim de Oliveira, J. A. (Eds.), Green Growth: Ideology, Political Economy and the Alternatives (pp. 131-149). London: Zed Books.

Martinez-Alier, J. Demaria, F., Temper, L., \& Walter, M. (2016). Trends of social metabolism and environmental conflict: A comparison between India and Latin America. In Dale, G., Mathai, M. V. and Puppim de Oliveira, J. A. (Eds.), Green Growth: Ideology, Political Economy and the Alternatives (pp. 187-210). London: Zed Books.

Meadway, J. (2016). Degrowth and the roots of neoclassical economics. In Dale, G., Mathai, M. V. and Puppim de Oliveira, J. A. (Eds.), Green Growth: Ideology, Political Economy and the Alternatives (pp. 90-111). London: Zed Books.

Pickett, K., \& Wilkinson, R. (2009). The Spirit Level: Why more equal societies almost always do better. London: Allen Lane.

PricewaterhouseCoopers LLP (2017). Is Paris Possible? The Low Carbon Economy Index 2017. Retrieved 7 April 2018, from https://www.pwc.co.uk/sustainability-climate-change/assets/pdf/lcei-17-pdf-final-v2.pdf

Rockstrom, J., Steffen. W., Noone, K., Persson, Å., Chapin III, F.S., Lambin, E.F., Lenton, T.M., Scheffer, M., Folke, C., Schellnhuber, H.J., Nykvist, B., de Wit, C.A., Hughes, T., van der Leeuw, S., Rodhe, H., Sörlin, S., Snyder, P.K., Costanza, R., Svedin, U., Falken- mark, M., Karlberg, L., Corell, R.W., Fabry, V.J., Hansen, J., Walker, B.H., Liverman, D., Richardson, K., Crutzen, P. \& Foley, J.A. (2009). A Safe Operating Space for Humanity. Nature, 461, 472-475.

Rogers, H. (2010). Green Gone Wrong: How our economy is undermining the environmental revolution. New York: Simon and Schuster.

Shin, Hyon-hee (2013). South Korea ditching green growth. The Korea Herald (online). Published in the Asia News Network. Retrieved 27 August 2013, from www.asianewsnet.net/South-Korea-ditchinggreen-growth-44753.html
Smith, Adam (1993 [1776]). The Wealth of Nations. Oxford: Oxford University Press.

Smith, R (2014, January 15). Beyond Growth or Beyond Capitalism? Truthout . Retrieved 12 March 2015, from http://www.truth-out.org/news/item/21215-beyond-growth-or-beyond-capitalism\#

Stiglitz, J. E.; Sen, A. and Fitoussi, J-P (2009). Report by the Commission on the Measurement of Economic Performance and Social Progress. Retrieved 6 November 2016, from http://www.stiglitz-sen-fitoussi.fr/documents/rapport_anglais.pdf

Sunderlin, William (2003). Ideology, Social Theory and the Environment. Lanham, MD: Rowman \& Littlefield.

Taminiau, J., \& Byrne, J. (2016). Reconsidering growth in the greenhouse: The Sustainable Energy Utility (SEU) as a practical strategy for the twenty-first century. In Dale, G., Mathai, M. V. and Puppim de Oliveira, J. A. (Eds.), Green Growth: Ideology, Political Economy and the Alternatives (pp. 233-252). London: Zed Books.

Tierney, J. (2009, April 20). Use energy, get rich and save the planet. The New York Times. Retrieved 25 May 2011, from http://www.nytimes.com/2009/04/21/ science/earth/21tier.html

World Bank (2017). World GDP per capita growth (annual \%). Retrieved 11 August 2017, from http://data. worldbank.org/indicator/NY.GDP.PCAP.KD.ZG

WEC-World Energy Council (2016). World Energy Perspectives Energy Efficiency: A Straight Path Towards Energy Sustainability. London: The World Energy Council in partnership with ADEME. 